\title{
INFLUENCE OF NITROGEN CONTENT ON RICE LEAF SHEATHS ON SHEATH BLIGHT
}

\section{DEVELOPMENT}

Influência do conteúdo de nitrogênio nas bainhas de arroz no desenvolvimento da queima das bainhas

Daniel Augusto Schurt ${ }^{1}$; Henrique da Silva Silveira Duarte²; Ueder Pedro Lopes 3 ; Fabrício de Ávila Rodrigues ${ }^{*}$

\begin{abstract}
${ }_{1}^{1}$ Pesquisador; Empresa Brasileira de Pesquisa Agropecuária; daniel.schurt@embrapa.br
${ }_{2}^{2}$ Professor; Departamento de Fitotecnia e Fitossanitarismo; Universidade Federal do Paraná; henriqueduarte@ufpr.br 3Professor; Unidade Acadêmica de Garanhuns; Universidade Federal Rural de Pernambuco; ueder.lopes@ufrpe.br

4Professor; Departamento de Fitopatologia; Universidade Federal de Viçosa; fabricio@ufv.br
\end{abstract}

Artigo enviado em 17/06/2016, aceito em 16/02/2017 e publicado em 03/03/2017.

Resumo - Este estudo objetivou avaliar o efeito de diferentes doses de nitrogênio (N) no desenvolvimento da queima da bainha do arroz (Rbizoctonia solani). Plantas de arroz das cultivares BR-IRGA 409 e Labelle foram crescidas em solução nutritiva contendo 0,50 e $100 \mathrm{mM}$ de $\mathrm{N}$. O progresso da queima da bainha foi avaliado medindo-se o comprimento relativo da lesão às 48, 72, 96 e 120 horas após inoculação. Os dados foram usados para calcular a área abaixo da curva do progresso do comprimento relativo de lesão (AACPCRL). À medida que as doses de $\mathrm{N}$ aumentaram de 0 para $100 \mathrm{mM}$, a concentração de $\mathrm{N}$ nas bainhas aumentou em 100 e $120 \%$ e a AACPCRL aumentou em 17,6 e 23,6\% para as cultivares Labelle e BR-IRGA 409, respectivamente. Os resultados demonstraram que a alta concentração de $\mathrm{N}$ nas bainhas das plantas de arroz das cultivares Labelle e BR-IRGA 409 favoreceu o desenvolvimento da queima da bainha.

Palavras-Chave - Oryza sativa, Rbizoctonia solani, resistência do hospedeiro, macronutriente, nutrição de plantas.

Abstract - This study aimed to evaluate the effect of different nitrogen $(\mathrm{N})$ rates on sheath blight (Rhizoctonia solani) development. Plants from rice cultivars BR-IRGA 409 and Labelle were grown in nutrient solution containing 0,50 and $100 \mathrm{mM}$ of N. Sheath blight progress on inoculated leaf sheaths was evaluated by measuring the relative lesion length at 48, 72, 96 and 120 hours after inoculation. Data was used to calculate the area under the relative lesion length progress curve (AURLLPC). The N concentration on leaf sheaths increased by 100 and $122 \%$ for cultivars Labelle and BR-IRGA 409, respectively, as the $\mathrm{N}$ rates increased from 0 to $100 \mathrm{mM}$. The AURLLPC increased by 17.6 and $23.6 \%$ for cultivars Labelle and BR-IRGA 409, respectively, as the $\mathrm{N}$ rates increased. The results suggest that a high concentration of $\mathrm{N}$ on leaf sheaths of plants from cultivars Labelle and BR-IRGA 409 favored sheath blight development.

Keywords - Oryza sativa, Rbizoctonia solani, host resistance, macronutrient, plant nutrition.

\section{INTRODUCTION}

Sheath blight, caused by Rhizoctonia solani Kühn (Thanatephorus cucumeris (A. B. Frank) Donk), is considered one of the most devastating disease in rice world-wide (JIA et al., 2012; TAGUCHISHIOBARA et al., 2013). This disease causes serious yield losses mainly due to the use of susceptible rice cultivars, plantations in irrigated areas, crop rotation with soybean and climatic conditions that are favorable to the occurrence of severe epidemics (YELLAREDDYGARI et al., 2014).

Resistant cultivars are not commercially available to growers, therefore sheath blight management is based on fungicides and cultural control (GROTH, 2008; YELLAREDDYGARI et al., 2014). Mineral nutrition has been used as a complement in disease management because host resistance against infection by pathogens can be affected by nutrient deficiency or toxicity 
(MARSCHNER, 1995). Among the nutrients, the nitrogen $(\mathrm{N})$ has been widely studied due to its effect on plant diseases (HUBER and THOMPSON, 2007). It is involved in almost all physiological processes in the plant, including the production of amino acids, proteins, enzymes, hormones, phytoalexins and phenolic compounds and other cellular process. It also promotes vigorous plant growth, delays maturity and affects cell size and wall thickness (RICE, 2007; HUBER and THOMPSON, 2007).

Application of $\mathrm{N}$ is required in order to increase productivity in commercial rice crops (SLATON et al., 2003). This is becoming more common especially with the use of cultivars with high yields requiring high doses of $\mathrm{N}$ (NORMAN; WILSON; SLATON, 2003). Although the application of $\mathrm{N}$ can increase the productivity in rice crop, many studies have reported the increased sheath blight intensity by $\mathrm{N}$ application (CU et al., 1996; SLATON et al., 2003; TANG et al., 2007). Most of the research was carried out with plants under field conditions and the effect of $\mathrm{N}$ on sheath blight was associated with an increase in plant leaf area. However, there is little information on the literature regarding other mechanisms besides the change in leaf area and the microclimate in plants supplied with high $\mathrm{N}$ rates in favor sheath blight development. Therefore, the objective of this study was to investigate the effect of different $\mathrm{N}$ rates on sheath blight progress in two rice cultivars (BR-IRGA 409 and Labelle) grown in nutrient solution under controlled conditions.

\section{MATERIAL AND METHODS}

Rice seeds were washed in sodium hypochlorite solution (10\%) for $1.5 \mathrm{~min}$ and then washed in deionized water for $3 \mathrm{~min}$. The seeds were germinated in rolls of filter paper $(15 \times 15 \mathrm{~cm})$ soaked with water and kept at $25^{\circ} \mathrm{C}$. Six seedlings were maintained in each plastic pot $(40 \times 25 \times 8 \mathrm{~cm})$ containing 5 liters of nutrient solution consisting of: $1.0 \mathrm{mM} \quad \mathrm{KNO}_{3}, 0.25 \mathrm{mM} \quad \mathrm{NH}_{4} \mathrm{H}_{2} \mathrm{PO}_{4}, 0.1 \mathrm{mM}$ $\mathrm{NH}_{4} \mathrm{Cl}, 0.5 \mathrm{mM} \mathrm{MgSO} 4.7 \mathrm{H}_{2} \mathrm{O}, 1.0 \mathrm{mM} \mathrm{Ca}\left(\mathrm{NO}_{3}\right)_{2}$, $0.30 \mu \mathrm{M} \mathrm{CuSO} 4.5 \mathrm{H}_{2} \mathrm{O}, 0.33 \mu \mathrm{M} \mathrm{ZnSO} 4.7 \mathrm{H}_{2} \mathrm{O}, 11.5$ $\mu \mathrm{M} \quad \mathrm{H}_{3} \mathrm{BO}_{3}, \quad 3.5 \mu \mathrm{M} \quad \mathrm{MnCl}_{2} .4 \mathrm{H}_{2} \mathrm{O}, \quad 0.1 \mu \mathrm{M}$ $\left(\mathrm{NH}_{4}\right)_{6} \mathrm{Mo}_{7} \mathrm{O}_{24} 4 \mathrm{H}_{2} \mathrm{O}, 25 \mu \mathrm{M} \mathrm{FeSO} 4.7 \mathrm{H}_{2} \mathrm{O}$ and 25 $\mu \mathrm{M}$ EDTA. The nutrient solution was replaced every four days or when the electrical conductivity was $85 \%$ of the initial value and maintained between 5.5 and 6.0 .

Rice seedlings from cultivars BR-IRGA 409 and Labelle, which are susceptible to $R$. solani (PRABHU et al., 2002), were transplanting to nutrient solution and grown until 45 days after transplanting (dat). At 45 dat, plants were removed from this nutrient solution and transferred to plastic pots containing nutrient solutions with the concentrations of 0,50 and $100 \mathrm{mM}$ of $\mathrm{N}$. Plants (60-days old, maximum tillering stage) were inoculated by placing a $1 \mathrm{~cm}$ toothpick colonized by R. solani into the lowest inner sheath of the main tiller. Immediately after inoculation, all plants were transferred to a plastic mist chamber in greenhouse. After 24 hours, the inoculated plants were removed from the mist chamber and maintained in greenhouse at $25^{\circ} \mathrm{C}$.

Sheath blight lesion expansion on the inoculated leaf sheaths was measured at 48, 72, 96 and 120 hours after inoculation (hai). The relative lesion length (RLL) was calculated by dividing the lesion length $(\mathrm{cm})$ by the sheath length $(\mathrm{cm})$ and multiplying by 100 . Data from RLL were used to calculate the area under relative lesion length progress curve (AURLLPC). At the end of the experiments, leaf sheaths were removed and the $\mathrm{N}$ concentration was determined using the semimicro Kjeldhal method.

A factorial experiment $3 \times 2$ consisting of three $\mathrm{N}$ rates and two cultivars (BR-IRGA 409 and Labelle) was arranged in a completely randomized design with three replications. The experiment was repeated once. Cochran's test for homogeneity of variance indicated that the AURLLPC and $\mathrm{N}$ concentration data from two experiments could be pooled for data analysis. Data from $\mathrm{N}$ concentration on leaf sheaths and the AURLLPC were submitted to verification of the assumptions of normality, homogeneity and independence of experimental error and analysis of variance. A regression analysis based on the $\mathrm{N}$ rates and two cultivars was performed. The cultivars BR-IRGA 409 and Labelle were coded as 0 and 1 , respectively. The highest coefficients of the model used were tested by Student's test $(P<0.05)$ to the best fit model with all significant terms as follows: $Y i=\beta_{0}+\beta_{1} R_{i}+\beta_{2} R_{i}^{2}+\beta_{3} C_{i}+\beta_{4} R_{i} C_{i}+e_{i}$; where $\mathrm{Y}_{\mathrm{i}}=$ observed value of the variable in the observation $\mathrm{i}(\mathrm{i}=1,2,3 \ldots 36) ; \mathrm{R}_{\mathrm{i}}=\mathrm{N}$ rate in the observation $\mathrm{i}(0,50$ and $100 \mathrm{mM}) ; \mathrm{C}_{\mathrm{i}}=$ cultivars for the observation $\mathrm{i}(0=$ BR-IRGA 409 and $1=$ 
Labelle); $\beta_{0}=$ constant regression; $\beta_{1}, \beta_{2}, \beta_{3}$ and $\beta_{4}=$ regression coefficients; and $e_{i}=$ the regression error associated with the observed value $y$.

\section{RESULTS AND DISCUSSION}

The RLL from 48 to 120 hai was greater on leaf sheaths of plants grown at the highest $\mathrm{N}$ rate, reaching more than $50 \%$ at 120 hai, regardless of cultivar (Fig. 1a and b).

A linear model was the most suitable to describe the relationship between the AURLLPC and the $\mathrm{N}$ rates for both cultivars showing, therefore, that they had a similar behavior regarding their increased susceptibility to sheath blight as the $\mathrm{N}$ rates in the nutrient solution increased. The AURLLPC increased by 17.6 and $23.6 \%$ for cultivars Labelle and BRIRGA 409, respectively, as the $\mathrm{N}$ rates in the nutrient solution increased from 0 to $100 \mathrm{mM}$ (Fig. 2a). The $\mathrm{N}$ concentration on leaf sheaths increased linearly as the $\mathrm{N}$ rates in the nutrient solution increased. The $\mathrm{N}$ concentration on leaf sheaths increased by 100 and $122 \%$ for cultivars Labelle and BR-IRGA 409, respectively, as the $\mathrm{N}$ rates in nutrient solution increased from 0 to $100 \mathrm{mM}$ (Fig. 2b).
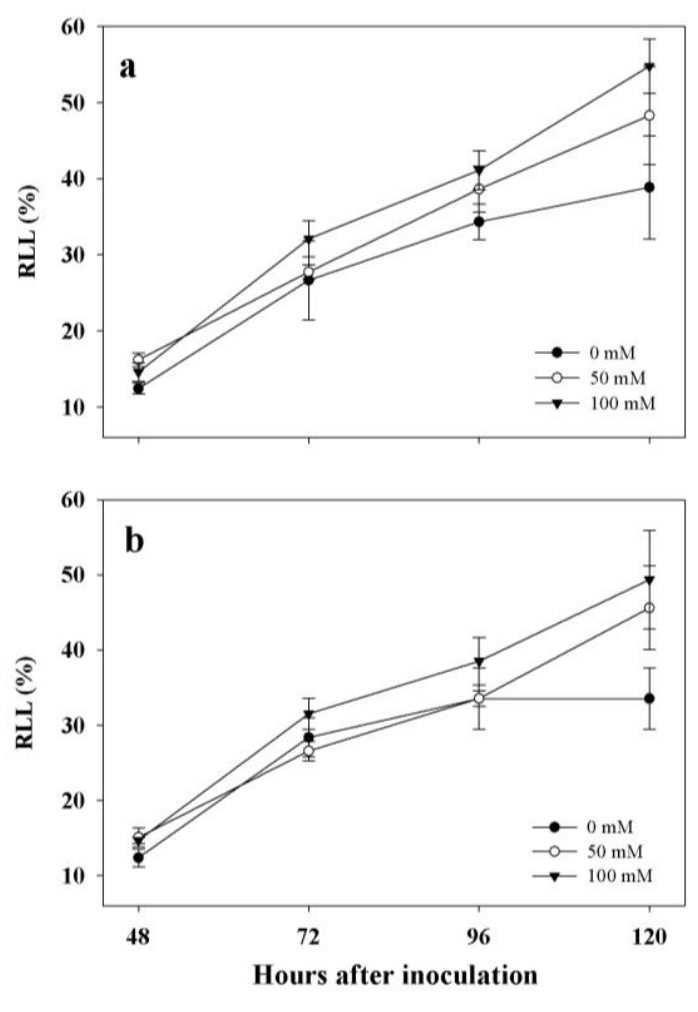

Figure 1- Relative lesion length (RLL) progress curves on leaf sheaths of rice plants from cultivars BR-IRGA 409 (a) and Labelle (b) grown in nutrient solution containing different nitrogen rates $(0,50$ and $100 \mathrm{mM})$. The error bars represent the standard error of the mean. Data were obtained from two pooled experiments. $n=6$.

Data obtained in the present study showed that high $\mathrm{N}$ concentration in the leaf sheaths was directly associated with the ability of $R$. solani in causing larger lesions. It can be suggested that providing high $\mathrm{N}$ rates can favor sheath blight development due to changes beyond those related to greater foliage of the plants and changing the microclimate. In the present study, plants were kept in pots under the same environmental condition. It is possible that the high $\mathrm{N}$ concentration on leaf sheaths favor pathogen infection due to changes in the mechanical resistance of the tissues. 

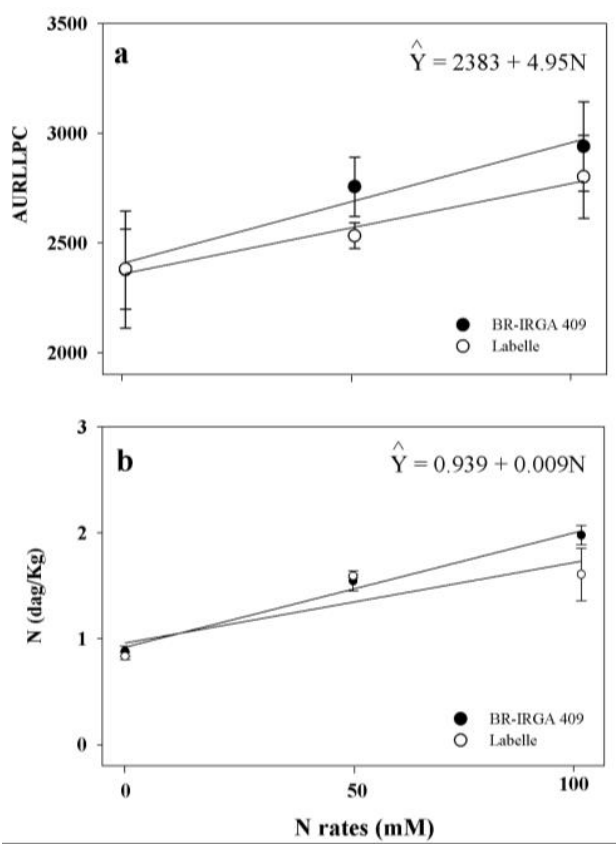

Figure 2- Area under relative lesion length progress curve (AURLLPC) (a) and nitrogen content (N $(\mathrm{dag} / \mathrm{Kg})$ ) (b) on leaf sheaths of rice plants from cultivars BR-IRGA 409 and Labelle grown in nutrient solution containing different $\mathrm{N}$ rates. The error bars represent the standard error of the mean. Data were obtained from two pooled experiments. $n=6$.

\section{REFERENCES}

CALDWELL, P. M.; WARD, J. M. J.; MILES, N.; LAING, M. D. Assessment of the effects of fertilizer applications on gray leaf spot and yield in maize. Plant Disease, v.86, p. 859-866, 2002.

CU, R.; MEW, T. W.; CASSMAN, K. G.; TENG, P. S. Effect of sheath blight on yield in tropical, intensive rice production system. Plant Disease, v. 80, n. 8, p. 1103-1108, 1996.

GROTH, D. E. Effects of cultivar resistance and single fungicide application on rice sheath blight, yield, and quality. Crop Protection, v. 27, n. 7, p. 1125-1130, 2008.
The excess of $\mathrm{N}$ may inhibit the production of host defense compounds in response to pathogens infection (HUBER 1980). Caldwell et al. (2002) studying the effect of the different rates of $\mathrm{N}$ applied in maize observed increase of gray leaf spot for the biggest $\mathrm{N}$ rate. Tomato plants that received $\mathrm{N}$ application were more susceptible to Oidium lycopersicum (HOFFLAND; JEGER; BEUSICHEM, 2000). Some foliar pathogens are able to penetrate and colonize the plant tissues more rapidly when plants are grown under high levels of $\mathrm{N}$, mainly because changes in the amount of cellulose in the plant cell wall affect the mechanical resistance of the tissues (HUBER and THOMPSON, 2007).

\section{CONCLUSION}

A high nitrogen content on rice leaf sheaths favored sheath blight development.

HOFFLAND, E.; JEGER, M.J.; VAN BEUSICHEM, M. L. Effect of nitrogen supply rate on disease resistance in tomato depends on the pathogen. Plant and Soil, v. 18, n. 1, p. 239247, 2000.

HUBER, D. M. The role of mineral nutrition in defense. In: HORSFALL, J. G.; COWLING, E. B. Plant Disease: An Advanced Treatise, Academic Press. p. 381-406, 1980.

HUBER, D. M.; THOMPSON, I. A. Nitrogen and plant disease. In: DATNOFF, L. E, ELMER, W. H.; HUBER, D. M. Mineral Nutrition and Plant Disease, APS Press. p. 31-44, 2007. 
JIA, L.; YAN, W.; ZHU, C.; AGRAMA, H. A.; JACKSON, A.; YEATER, K.; LI, X.; HUANG, B.; HU, B.; MCCLUNG, A.; WU, D. Allelic analysis of sheath blight resistance with association mapping in rice. Plos One, v.7, n. 3, p. 32703, 2012.

MARSCHNER, H. Mineral Nutrition of Higher Plants. Academic Press, 1995.

NORMAN, R. J.; WILSON, C. E.; SLATON, N. A. Soil fertilization and mineral nutrition, in U.S mechanized rice culture. In: SMITH, C.W.; DILDAY, R.H. Rice, technology, bistory and production, John Wiley. 2003, p. 331-412.

PRABHU, A. S.; FILIPPI, M. C.; SILVA, G. B.; SILVA, G. R. Resistance of rice cultivars to Rhizoctonia solani and Rhizoctonia oryzae. Pesquisa Agropecuária Brasileira, v. 7, n. 5, p. 589-595, 2002.

RICE, R. W. The physiological role of minerals in the plant. In: DATNOFF, L. E.; ELMER, W.H.; HUBER, D. M. Mineral Nutrition and Plant Disease, APS Press, 2007, p. 09-29.
SLATON, N. A.; CARTWRIGHT, R. D.; MENG, J.; GBUR, E. E.; NORMAN, R. J. Sheath blight severity and rice yield as affected by nitrogen fertilizer rate, application method, and fungicide. Agronomy Journal, v. 95, n. 6, p. 489-1496, 2003.

TAGUCHI-SHIOBARA， F.; OZAKI， H.; SATO, H.; MAEDA, H.; KOJIMA, Y.; EBITANI, T.; YANO, M. Mapping and validation of QTLs for rice sheath blight resistance. Breeding Science, v. 63, n. 3, p. 301-308, 2013.

TANG, Q.; PENG. S.; BURESH, R. J.; ZOU, Y.; CASTILLA, N. P.; MEW, T. W.; ZHONG, $\mathrm{X}$. Rice varietal difference in sheath blight development and its association with yield loss at different levels of $\mathrm{N}$ fertilization. Field Crops Research, v. 102, n. 3, p. 219-227, 2007.

YELLAREDDYGARI, S. K. R.; REDDY, M. S.; KLOEPPER, J. W.; LAWRENCE, K. S.; FADAMIRO, H. Rice Sheath Blight: A Review of Disease and Pathogen Management Approaches. Journal Plant Pathology Microbiology, v. 5, n. 4, p. 241, 2014. 